$$
\begin{aligned}
& \text { : العقــاق }
\end{aligned}
$$

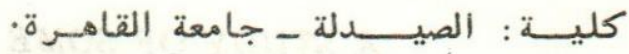

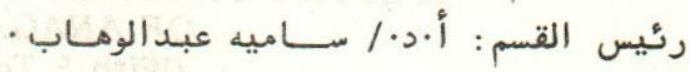

دراسة عن بعض الخصائص الفارماكوديناميكيه لنبات أناجالس أرفينسيس

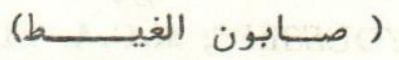

سيد هلال ، صلاح الدين عبد الحميد، مسعد جمال ، مصطفى شلببي ، سيد أبوطبــلـ

تناولت هذه الدراسة بعض الخصائص الفارماكولوجيه على الخلاصة الكحولية لنبــــات النـات

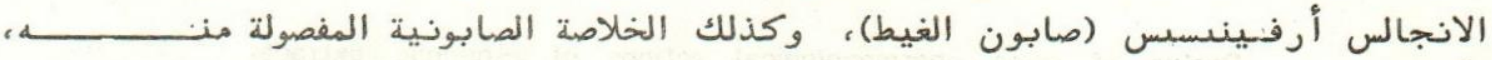

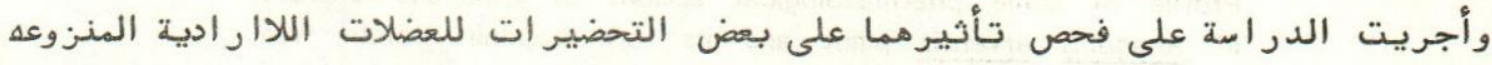

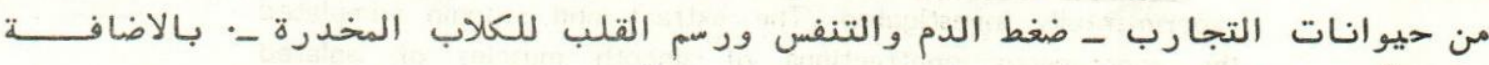

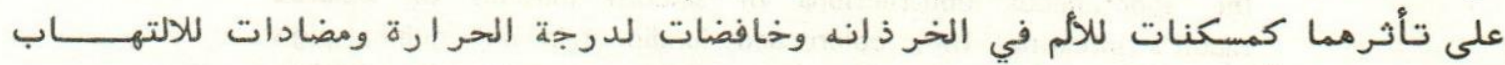

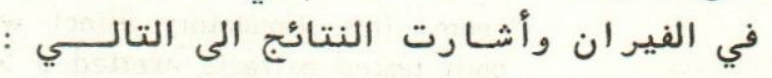

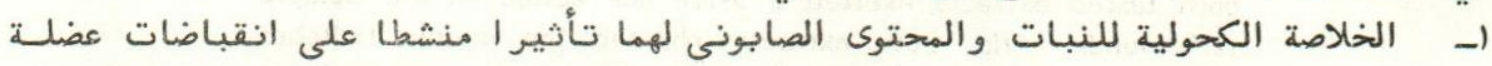

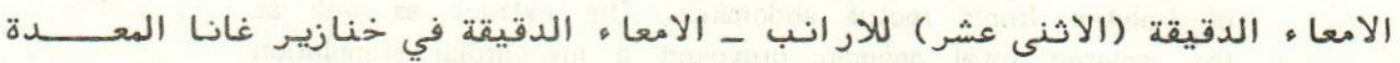

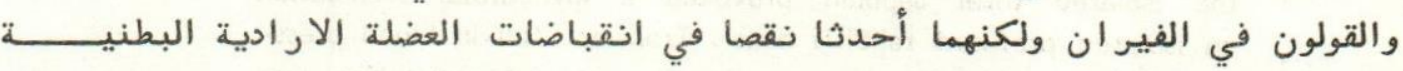

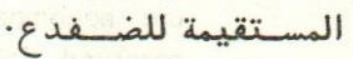

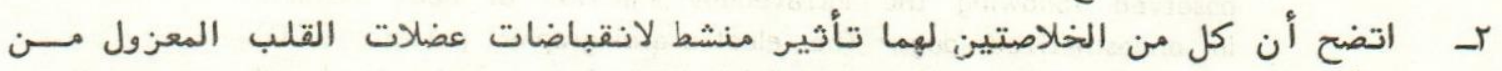

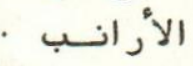

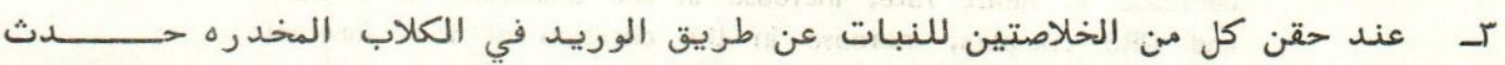

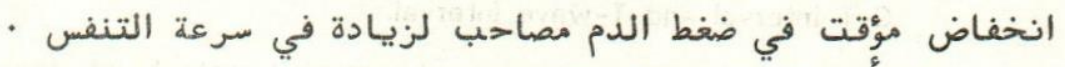

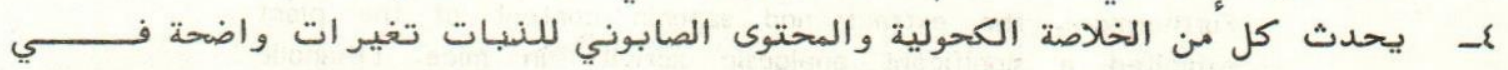

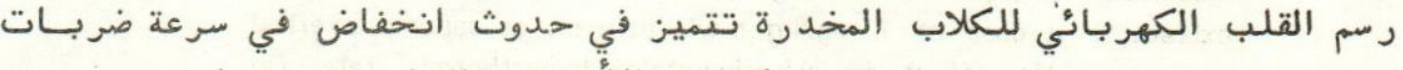

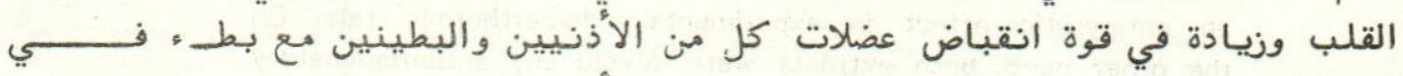

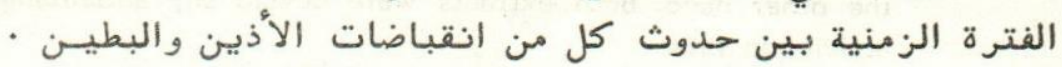

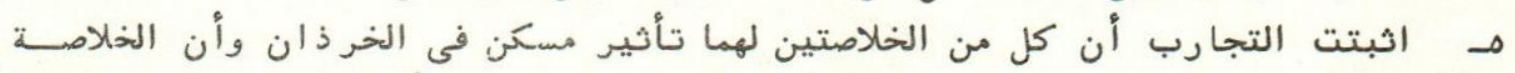

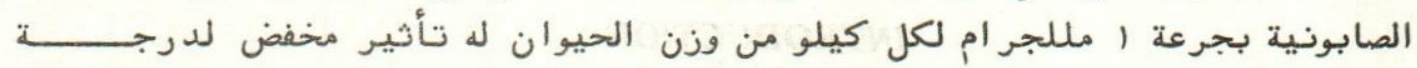

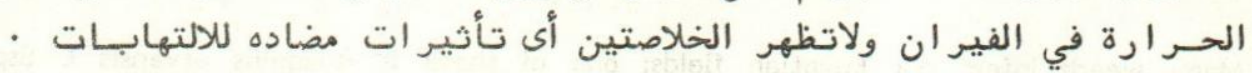


Dept. of Pharmacognosy,

Faculty of Pharmacy, Cairo University,

Head of Dept. Prof. Dr. Samia Abdel Wahaab.

\title{
A STUDY OF SOME PHARMACODYNAMIC ACTIONS OF ANAGALLIS ARVENSIS
}

(With 5 Tables \& 11 Figs.)

\author{
By \\ S.H. HILAL; S.A.H. YOUSSEF*; M.G.A. EL-SAYED*; M.A. SHALABY* \\ and $E_{.}$A. ABOUTABL \\ (Received at 7/9/1986)
}

\begin{abstract}
SUMMARY
Profile of some pharmacological actions of ethanolic extract of Anagallis arvensis plant and its total saponin isolate was experimentally investigated. The extract and saponin stimulated the spontaneous contractions of smooth muscles of isolated rabbit's intestine, rat's colon and fundic strip and guinea pig's ileum. This stimulatory effect was dose-dependent. In addition, both tested extracts exerted a 5-HT like action on the isolated rat's fundic strip. Both extracts inhibited the muscle twitches of isolated frog's rectus abdominus. The extract as well as the isolated total saponin provoked a myocardial stimulation on isolated prefused rabbit's heart. Transient fall in blood pressure accompanied with increase in the rate of respiration was observed following the intravenous injection of both extracts in anaesthetized dogs. The electrocardiographic pattern (ECG) following the intravenous administration of both extracts showd decrease in heart rate, increase in the amplitude of $P$-wave and QRS complex, increase in the duration of $P-R$ interval, Q-T interval and $\mathrm{T}$-wave interval.

Furthermore, the extract and saponin content of the plant exhibited a significant analgesic activity in mice. Ethanolic extract in a dose of $1 \mathrm{mg} / \mathrm{kg}$ b.wt. as well as saponin exerted an antipyretic effect in experimentally hyperthermic rats. On the other hand, both extracts were devoid any antiinflammatory activity in rats.
\end{abstract}

\section{INTRODUCTION}

Many weeds infest our Egyptian fields; one of these is Anagallis arvensis L Ssp. arvensis plant (Family Primulaceae) "Red Primpernel or Saboun el-Gheit" (SHARAF, 1928; TACKOLM, 1974). Phytochemical studies on the plant indicated the presence of unsaturated sterols and/or triterpens in the extract of all organs, while carbohydrates and/or glucosides, catechol tannins, saponins mainly triterpen oid saponin glucosides and flavenoids in the ethanol (95\%) extractives (DARCHAl, et al. 1968; HILAL, et al. 1985). According to the folk medicine (SHARAF, 1928

* Dept. of Pharmacology, Fac. of Vet. Med., Cairo \& Zagazig Univ.

Assiut Vet.Med.J. Vol. 18, No. 35, 1987. 
S.H. Hil.AL, et al.

and BENSON, 1957), the plant has been used for a long time for treatments of wound, inflammations, renal retention, rheumatism and toothache. Although some investigators (SHIHATA, 1951; CHOPRA, 1958 and KINGSBURG, 1964), have studied the toxicological effects of the plant in different animal species, only few have been concerned with the pharmacological properties of this plant (SHIHATA, 1951 and HILAL, et al. 1985).

The present report describes the influence of the ethanolic extract and the isolated total saponin of Anagallis arvensis on digestive smooth muscles and skeletal muscles of some organs, systemic blood pressure, respiration and ECG pattern of anaesthetized dogs. In addition, the analgesic antipyretic and antiinflammatory activities of both extracts were also studied.

\section{MATERIAL and METHODS}

\section{A- Material for pharmacological testing:}

\section{Ethanolic extract of Anagollis arvensis:}

The powder of air-dried whole plant $(200 \mathrm{~g})$ was exhaustively extracted by percolation with ethanol (90\%). The solvent was stripped off and the residue was dissolved in 10\% Tween 80 in distilled water to obtain solution of which $1 \mathrm{ml}$ is equivelent to $1 \mathrm{~g}$ powder.

\section{2. purified saponin of Anagallis arvensis:}

The total saponin content of the plant was isolated as described in our previous communication (HILAL, et al. 1985). Accurately weighed aliquots of the saponin were dissolved in distilled water to provide known concentrations intended for different pharmacological tests.

\section{B- Effect on isolated digestive smooth muslce preparations:}

Pieces of guinea pig's ileum, rabbit's duodenum, rat's colon and rat's fundic strip were suspended in glass Jar bath of $50 \mathrm{ml}$ capacity containing the oxygenated respective physiological solution at $37^{\circ} \mathrm{C}$ (ROBELLA, et al. 1928). Before testing the effects of graded concentrations of both ethanolic extract and saponin content of Anagalis arvensis, the normal rhythmic contractility of each organ was recorded. The $T_{2}$ isotonic transducer connected with Oscillograph MD (Bioscience) was used for recording the contractions of each preparation. Attempts were also made to locate the site of action of both tested extracts on isolated rabbit's duodenum and rat's fundic strip.

\section{C- Effect on frog's rectus abdominis muscle:}

The effect of different concentrations of ethanolic extract and saponin content of Anagalis arvesis on frog's rectus abdominis was determined according to the method described by BURN (1952). The contractions were traced using $T_{2}$ isotonic transducer connected with Oscillograph $\mathrm{MD}_{2}$.

D- Effects on isolated rabbit's heart, systemic blood pressure, respiration and ECG of anaesthetized dogs:

The rhythmic contractility of the isolated rabbit's heart was recorded using Gunn's apparatus (CHAPMAN, et al. 1972 and $T_{2}$ isotonic transducer connected with MD $_{2}$ Oscillograph.

The systemic blood pressure, respiration and ECG were recorded in anaesthetized mongrel dogs of both sex using a 4-channel Oscillograph $\mathrm{MD}_{4}$ (Biosience). The right femoral artery was 


\section{PHARMACODYNAMIC ACTIONS OF ANAGALLIS}

connected to a Mercury manometer, while the left femoral artery was connected to PT $400^{\circ}$ blood pressure transducer. The respiratory rate was recorded using Stethograph attached to a tambour connected with $T_{2}$ isotonic transducer. The ECG was recorded by a standard Lead II. The effect of graded concentrations of extract and total saponin of the tested plant was demonstrated.

\section{E- Analgesis effect:}

The hot plate method as described by JACOB and BOSVSKI (1961) was used. 30 mice of either sex weighing 20-25 g were divided into 6 groups each of 5 animats. The 1st group was left as non-treated control and animals within the 2nd group were injected subcutaneously with acetylsalicylic acid ( $5 \mathrm{mg} / 100 \mathrm{~g} . \mathrm{b} . \mathrm{wt}$ ) and considered as standard. Animals within the 3rd, 4th, 5th and 6th groups were given orally 0.5, 1 (of the ethanolic extract), 0.2 and $0.4 \mathrm{mg} / 100$ g.b.wt (of saponin) respectively. After treatment, each mouse was placed in a 2 liters beaker immersed in a water bath thermostatically controlled at $56+0.5^{\circ} \mathrm{C}$. The time elapsed until the mouse licks the paws or jumps was considered as the reaction time for the analgesic activity. This parameter was recorded $10,20,30,45,60$ and 120 minutes after administration. The reaction time was calculated and used as the response to the injected dose at the respective time interval.

\section{F- Antipyretic effect:}

30 mature albino rats of either sex weighing 180-200 g. were divided into 6 groups and are made hyperthermic by subcutaneous injection of $12 \%$ yeast suspension $(1 \mathrm{ml} / \mathrm{kg}$ b.wt) as described by TEOTINO, et al. (1963). After 15 hours, the temperature of each rat was recorded using medical thermometer. The 1st group was left as hyperthermic control and the 2nd group was injected subcutaneously with acetyl salicylic acid ( $5 \mathrm{mg} / 100 \mathrm{~g} \cdot \mathrm{b} . \mathrm{wt}$ ) and left as standard. The 3rd, 4th, 5th and 6th groups were given ethanolic extract $(0.5$ and $1 \mathrm{mg} / 100 \mathrm{~g}$. b.wt) and saponin ( 0.2 and $0.4 \mathrm{mg} / 100 \mathrm{~g} . \mathrm{b} . \mathrm{wt})$ of Anagalis arvensis respectively. The rectal temperature of each rat was then recorded hourly for 3 hours. The differences in temperature between the treated groups and the control was taken as a measure of antipyretic activity.

\section{G- Anti-inflammatory effect:}

The method of DOMENJOZ, et al. (1955), which depends on induction of pedal inflammation in rat's foot by formalin (4\%) was used. Similar groups of rats as described for antipyretic effect were used to study the antiinflammatory activity of the ethanolic extract as well as the isolated total saponin of Anagallis arvensis plant. Rats inthe standard group were given intraperitoneally phenylbutazone $(\overline{3 \mathrm{mg} / 100} \mathrm{g.b.wt})$. The antiinflammatory effect was determined after measuring the pam's thickness before, after 3 and 6 hours administration of extracts using skin caliber.

Data were statistically analysed using Student's "t" test as described by SNEDECOR (1969).

\section{RESULTS}

\section{Effect on isolated digestive smooth muscle preparations:}

Both ethanolic extracts of Anagallis arvensis (up to $400 \mathrm{ug} / \mathrm{ml}$ bath) and total saponin (up to $0.4 \mathrm{ug} / \mathrm{ml}$ bath) stimulated the contractions of guinea pig's ileum, rat's colon and rabbit's duodenum (Figs. 1,2 and 3). This effect was dose-dependent.

This stimulatory effect of total saponin on rabbit's duodenum was myogenic in nature

Assiut Vet.Med.J. Vol. 18, No. 35, 1987. 
S.H. HILAL, et al.

as saponin induced its motor effect in the presence of atropine $(3.5 \mathrm{ug} / \mathrm{ml}$ ) and nicotine (2 $\mathrm{ug} / \mathrm{ml}$ ) as shown in Fig. 4. The stimulatory response of rat's fundic strip to both tested extracts was blocked by prior addition of cyproheptadine $\left(5 \times 10^{-6} \mathrm{~m} \mathrm{Mol} / \mathrm{L}\right)$. This proved that both extracts of Anagallis arvensis exhibited its stimulatory effect on rat's fundic strip by 5-HT like action (Fig. 5).

\section{Effect on Frog's rectus abdominis muscie:}

Ethanolic extract and total saponin of Anagallis arvensis in concentrations of 100 and $10 \mathrm{ug} / \mathrm{ml}$ bath respectively decreased the contractile response of muscle induced by acetylcholine (2 ug/ml bath) (Fig. 6).

\section{Haemodynamic effects:}

Total saponin of Anagallis arvensis in concentration up to $0.25 \mathrm{ug} / \mathrm{ml}$ caused a typical positive inotropic effect on isolated rabbit's heart than those observed with ethanolic extract of the plant $(0.5 \mathrm{ug} / \mathrm{ml}$ ) (Fig. 7). In addition, saponin exhibited a beta-adrenoceptor agonist like effect as its positive inotropic effect was abolished in the presence of propranolol (6 ug/ml) (Fig. 8).

The maximum changes in systemic blood pressure and respiration parameters after a single intravenous injection of different doses of ethanolic extract of the tested plant and its total isolated saponin and duration of action are summerized in table 1 and illustrated in Fig. (9). After a single injection of small doses of the extract and the saponin, the mean systolic and diastolic pressure were decreased by $8-20 \%$ but the difference was non-significant. After injection of a large single dose of extract $(9 \mathrm{mg} / \mathrm{kg})$ and saponin $(3 \mathrm{mg} / \mathrm{kg})$, the mean systolic and diastolic blood pressure were dignificantly decreased with an average duration of action of $45 \pm 6$ and $30 \pm 5$ minutes respectively. This transient hypotensive effect exhibited by both extracts was accompanied with a significant increase in the rate of respiration (Fig. 9).

Furthermore, the hypotensive action of saponin seemed to be myogenic in nature as saponin produced its hypotensive effect after i.v. injection of atropine sulhate $(1.5 \mathrm{mg} / \mathrm{kg})$, as well as it failed to block the hypertensive effect of nor-adrenaline (3 ug/ $\mathrm{kg} \mathrm{b.wt.,} \mathrm{j.v)} \mathrm{(Fig.} \mathrm{10).}$

Changes in the electrocardiographic pattern of anaesthetized dogs after the intravenous injection of ethanolic extract $(9 \mathrm{mg} / \mathrm{kg})$ and saponin $(3 \mathrm{mg} / \mathrm{kg})$ of Anagallis arvensis plant are incorporated in table 2 and illustrated in Fig. (11). Both extracts remarkebly decreased the heart rate, increased the amplitude and duration of $P$-wave and P-R interval. These changes were observed within 30 minutes after administration and then returned to their initial values after 60 minutes. Furthermore, the amplitude of QRS complex and Q-T wave duration were markedly increased and RS-T segment showed a slight lowering below the isoelectric line, but there was no changes in the duration of QRS complex. These changes persisted over a period of one hour after injection. On the other hand, the amplitute of $T$-wave was decreased by $80 \%$ after administration of both extracts. It was also noticed that the T-wave interval was extented after injection of the ethanolic extract but was shortened after administration of saponin of Anagallis arvensis.

\section{Analgesic effect:}

As shown in table (3), oral administration of ethanolic extract ( 0.5 and $1.0 \mathrm{mg} / 100 \mathrm{~g})$ and saponin $(0.2$ and $0.4 / \mathrm{mg} / 100 \mathrm{~g} . \mathrm{b} . \mathrm{wt})$ of Anagalis arvensis increased significantly the reaction time in mice exposed to hot plate at $56^{\circ} \mathrm{C}$. This effect persisted for a period of 120 minutes after administration. Furthermore, the analgesic effect induced by the large and small doses 


\section{PHARMACODYNAMIC ACTIONS OF ANAGALLIS}

of ethanolic extract and saponin was less potent than that proved by S.Cadministration of acetyIsalicylic acid ( $5 \mathrm{mg} / 100$ g.b.wt). Saponin in a dose level of $0.4 \mathrm{mg} / \mathrm{kg}$ was found to be more potent than analgesic effect induced by acetylsalicylic acid.

\section{Antipyretic effect:}

Saponin in doses of $0.2 \mathrm{mg} / 100 \mathrm{~g}$ (after 1 hour) and $0.4 \mathrm{mg} / 100 \mathrm{~g}$ (after 1,2 hours) was capable to decrease significantly the body temperature of hyperthermic rats. This antipyretic effect was less potent than that effect produced by acetylsalicylic acid $(5 \mathrm{mg} / 100 \mathrm{~g})$. On the contrary, the ethanolic extract $(0.5$ and $1.0 \mathrm{mg} / 100 \mathrm{~g})$ did not alter the body temperature of hyperthermic rats as compared with control hyperthermic rats (Table 4).

\section{Antiinflammatory effect:}

As shown in Table (5), both tested extracts did not exhibit any antiinflammatory effect as they are not able to decrease the swelling of rat's foot induced by formaline.

\section{DISCUSSION}

Our experiments have demonstrated that, the smooth muscles of gastrointestinal tract of different experimental animals as rabbit's duodenum, guinea pig's ileum, rat's colon and rat's fundic strip were remarkably stimulated by both ethanolic extract and total saponin of Anagallis arvensis. The intense and duration of this spasmodic response seemed to be dose dependent. In addition, the stimulatory effect induced by both extracts was proved to be myogenic in natu$\mathrm{re}$, as saponin exhibited its motor effect in the presence of atropine and large dose of nicotine. These findings were consistent with those reported by SHIHATA (1951), who denoted that Anagallis arvensis extract has an contractile response on the isolated rabbit's intestine. He added that this contractile response induced by the plant extract was pharmacologically identical with the glucosidal substance isolated from the same plant. Moreover, our findings could explain the incidence of gastroenteritis and diarrhoea following the accidental posioning with Anagallis arvensis in farm animals (WATT and BRAYER, 1932). On the other hand, the serotonin -like effect exhibited by both extracts on rat's fundic strip might be referred to 5-HT like action.

The stimulatory effect of both extracts denoted here' on the isolated smooth muscle preparations was inconsistent with those recorded on frog's rectus abdominus, as they decreased the contractile response of acetylcholine on the muscle.

Concerning the haemodynamic effects of Anagallis arvensis extract and its isolated saponin, it was found that both extracts exhibited a myocardial contractile response either in vivo or vitro. These changes represented by a marked myocardial stimulation (positive inotropic effect) on isolated rabbit's heart which can be antagonised by propranolol. Furthermore the significant electrophysiological alterations following the intravenous administration of both extract in normal anaesthetized dogs confirmed the in vitro findings. The decrease in heart rate, progressive increases in the amplitute in P-wave and QRS complex accompanied with lowering of RST segment and inverting of T-wave, increase in the duration of P-wave and Q-T wave intervals reflect to a greater extent that both tested extracts exhibited a dose dependent effect on the heart. Positve inotropic effect associated with similar electrocardiographic altrations have been reported for several cardiac glucosides as digitalis in normal non-arrhythmic heart (MASON, 1966) except in that digitalis $(0.5-2 \mathrm{mg} / \mathrm{kg}$ in normal man) shortens the Q-T intervals. In the present work, the isolated saponin but not the ethanolic extract of Anagallis

Assiut Vet.Med.1. Vol. 18, No. 35, 1987. 
S.H. HILAL, et al.

arvensis was found to shorten the $Q-T$ interval like digitalis. These features are probably due to the presence of tri-terpeniod saponin glucosides viz. B anagalligenin B.glucoside and anagalligenin B-rhamnoside content which were isolated and identified by HILAL, et al. 1985 from Anagallis arvensis plant.

According to MASON (1966), digitalis is the only drug that can increase the contractility of the heart when given to a normal human, however it slightly decreases the cardiac output. Accordingly, the transient fall of blood pressure exhibited by both tested extracts was anticepated, as our experiments are conducted in normal anaesthetized dogs.

Furthermore, the failure of atropine to antagonise the hypotensive effects induced by saponin and the failure of the saponin to prevent the hypertensive effect of noradrenaline as has been observed in our experiments, confirm our explanation. Moreover, SHIHATA (1951) reported that the ethanolic extract caused a marked fall in blood pressure following its intravenous injection in anaesthetized dogs.

In Folk medicine (SHARAF, 1928; TACKHOLM, 1974 and AL-BIRUNI, 1973), Anagallis arvensis is used for treatment against toothache, and rhumatism. In agreement with the previous authors, Anagallis arvensis extract and its total saponin exhibited an analgesic and antipyretic activities after oral administration in mice and hyperthermic rats respectively. The mechanism of tested extracts to induce both activities cannot be deduced from the present experiments. On the other hand, both extracts are devoid of any antiinflammatory activity.

In conclusion, Anagallis arvensis plant and its saponin content may be therapeutically used within safe dose limits as cardiac stimulant agent in heart failure, as analgesis and antipyretic agents but its spasmodic effect on the digestive smooth muscles should be taken in consideration. Further investigations should be carried out on the effect of the plants and saponin content in congestive heart failure cases.

\section{REFERENCES}

Al-Biruni, A. (1973): Pharmacy and Materia Medica. Hamdard National Foundation, Pakistan, Karatchi.

Benson, L. (1957): The plant classification, 205-206. D.C. Health and Company, Boston.

Burn, J.H. (1952): Practical pharmacology, 3-5, 1st Ed. Blackwell, Oxford.

Chapman, R.A.; Howard, L. and Tunstal, J. (1972): Experiments in physiology using Bioscience 400 series, Washington. Oscillograph.

Chopra, R.N. (1958): Chopra's Indigenous drugs of India; 2nd Ed., 583, U.N. Dhur Company, Calcutta.

Darchai, R.Q.; Rubalcaua, H.E. and Thomson, J.B. (1968): Tetrahedron Lett, 24, 5649-5654.

Domenjoz, R.; Theobald, W. and Morsdorf, K. (1955): Inflammation: Inhibitory effect of sodium salicylate. Arzneim Forsch., 5, 488-489.

Hilal, S.H.; Aboutabl, E.A.; El-Sayed, M.G.A.; Youssef, S.A.H. and Meselhy, M.R. (1985): The saponin of Anagallis arvensis L-ssp. arvensis: chemistry and sex hormone-like activity. Bull. Fac. Pharma., Cairo University, in Press.

Jacob, J. and Bosvski, M. (1961): Cited in Tuvner, R.A. (1956). Screening methods in pharmacology, 104, Academic Press, New York and London.

Kingsburg, J.M. (1964): Poisonous plants of United States and Canada, 250, Prentic-Hall, New Jercy.

Assiut Vet.Med.J. Vol. 18, No. 35, 1987. 
Mason, D.T. (1966): The cardiovascular effects of digitalis in normal man. Clin. Pharmacol. Therap., 7, 1-16.

Robella, S.; Gomes, S.F. and Rico, J.J. (1928): Actions of certain anthelmentics on cestodes, ascaris and ankylostomes. Sc., D. Biol., 98, 955-999.

Sharaf, M. (1928): An English-Arabic Dictionary, 2nd Ed., 54.

Shihata, I.M. (1951): A pharmacological study of Anagallis arvensis. M.D. Vet. Thesis Presented to Faculty of Veterinary Medicine, Cairo, Egypt.

Snedecor, G.W. (1969): Statistical methods. The lowa State University Press, lowa, U.S.A.

Tackolm, V. (1974): Student flora of Egypt., 2nd Ed., 399, Cairo Univ. Press, Egypt.

Teotino, U.M.; Taris, L.P., Candine, A. and Della Bella, D. (1963): Cited in Turner, R.A. (1965): Screening methods in Pharmacology, 298-299. Academic Press, Inc., New York.

Watt, J.M. and Brayer, B.M.G. (1932): The Medical and Poisonious Plants of South Africa. S.Livingstone, Edinburgh, 136.

Table (1)

Mean value $(x)$ and standard error $( \pm$ S.E) of systolic blood pressure (AP), diastolic blood pressure (DP) and respiration (Resp.) before and after a single intravenous injection of different doses of ethanolic extract of Anagallis arvensis plant and its isolated total saponin in anaesthetized dogs $(n=4) . P=$ Probability; ( ) Difference in \%; $n s=$ non-significant

\begin{tabular}{|c|c|c|c|c|c|c|c|}
\hline \multirow{3}{*}{$\begin{array}{l}\text { Dose } \\
(\mathrm{mg} / \mathrm{kg})\end{array}$} & \multirow{3}{*}{$\begin{array}{l}\text { Duration } \\
(\min .)\end{array}$} & \multicolumn{2}{|r|}{ AP } & \multicolumn{2}{|c|}{ DP } & \multicolumn{2}{|c|}{ Resp. } \\
\hline & & \multicolumn{2}{|c|}{$(\mathrm{mm} \mathrm{Hg})$} & \multicolumn{2}{|c|}{$(\mathrm{mm} \mathrm{Hg})$} & \multicolumn{2}{|c|}{ (Breath/min.) } \\
\hline & & Before & After & Before & After & Before & After \\
\hline 1. Extract & $30 \pm 5$ & $116+7$ & $\begin{array}{c}95.10 \\
(-18 \%) \\
\text { ns }\end{array}$ & $100+8$ & $\begin{array}{c}80 \pm 7 \\
(-20 \%) \\
n s\end{array}$ & $32+6$ & $\begin{array}{l}28+7 \\
(-12.5 \%) \\
\text { ns }\end{array}$ \\
\hline 9.0 & $45 \pm 6$ & $120 \pm 8$ & $\begin{array}{l}60 \pm 19 \\
(-50 \%) \\
P / 0.025\end{array}$ & $110+10$ & $\begin{array}{l}56+14 \\
(-49 \%) \\
P ! 0.01\end{array}$ & $38+4$ & $\begin{array}{r}74+8 \\
(+94.7 \%) \\
P / 0.01\end{array}$ \\
\hline 2. Saponin & $5 \pm 2$ & $100 \pm 17$ & $\begin{array}{c}\frac{9+5}{(-8 \%)} \\
\text { ns }\end{array}$ & $88 \pm 11$ & $\begin{array}{c}84+4 \\
(-4.5 \%) \\
n s\end{array}$ & $39 \pm 5$ & $\begin{array}{c}46+3 \\
(+18 \%) \\
\text { ns }\end{array}$ \\
\hline 1.0 & $10+3$ & $110 \pm 11$ & $\begin{array}{c}100+12 \\
(-9 \%) \\
\text { ns }\end{array}$ & $100 \pm 13$ & $\begin{array}{c}90+8 \\
(-9 \%) \\
\text { ns }\end{array}$ & $33+4$ & $\begin{array}{l}48+5 \\
(+45 \%) \\
P / 0.01\end{array}$ \\
\hline 2.0 & $15+4$ & $100+8$ & $\begin{array}{c}80+6 \\
(-20 \%) \\
n s\end{array}$ & $88 \pm 6$ & $\begin{array}{l}72+5 \\
(-19 \%) \\
P \geq 0.05\end{array}$ & $35 \pm 7$ & $\begin{array}{c}56+3 \\
(+60 \%) \\
P / 0.001\end{array}$ \\
\hline 3.0 & $30 \pm 5$ & $120 \pm 11$ & $\begin{array}{l}80+3 \\
(-3 \overline{3} \%) \\
P / 0.01\end{array}$ & $100 \pm 8$ & $\begin{array}{c}75+5 \\
(-29 \%) \\
P / 0.05\end{array}$ & $37 \pm 5$ & $\begin{array}{c}61+7 \\
(+64 \%) \\
P / 0.005\end{array}$ \\
\hline
\end{tabular}

Assiut Vet.Med.J. Vol. 18, No. 35, 1987. 
S.H. HILAL, et al.

Table (2)

Effect of intravenous injection of ethanolic extract of Anagallis arvensis

( $9 \mathrm{mg} / \mathrm{kg}$ b.wt) and its total saponin ( $3 \mathrm{mg} / \mathrm{kg} \mathrm{b.wt)}$

on electrocardiogram of anaesthetited dogs

\begin{tabular}{|c|c|c|c|c|c|c|c|c|c|c|c|c|}
\hline \multirow{3}{*}{ Prameter } & \multirow{3}{*}{ Before } & \multicolumn{5}{|c|}{ Extract } & \multicolumn{6}{|c|}{ Saponin } \\
\hline & & \multirow[b]{2}{*}{5} & \multicolumn{3}{|c|}{ After (mins) } & \multirow[b]{2}{*}{60} & \multirow{2}{*}{ Before } & \multicolumn{5}{|c|}{ After (mins) } \\
\hline & & & 10 & 15 & 30 & & & 5 & 10 & 15 & 30 & 60 \\
\hline $\begin{array}{l}\text { Heart rate } \\
\text { (Beats/min.) }\end{array}$ & 192 & 156 & 144 & 120 & 120 & 120 & 186 & 165 & 132 & 120 & 120 & 120 \\
\hline \multicolumn{13}{|l|}{ P-wave: } \\
\hline Ampo. $(\mathrm{mm})$ & 2.0 & 2.2 & 4.0 & 5.0 & 4.0 & 2.5 & 2.5 & 2.5 & 5.0 & 5.0 & 3.5 & 2.5 \\
\hline Duration (msec.) & 60 & 70 & 70 & 70 & 60 & 40 & 70 & 40 & 70 & 60 & 40 & 40 \\
\hline $\begin{array}{c}\mathrm{P}-\mathrm{R} \text { interval } \\
\text { (msec.) }\end{array}$ & 70 & 80 & 80 & 80 & 80 & 60 & 80 & 60 & 80 & 80 & 60 & 60 \\
\hline \multicolumn{13}{|l|}{ QRS-complex: } \\
\hline Amp. $(\mathrm{mm})$ & 9.0 & 9.5 & 10.5 & 14.0 & 14.5 & 14.5 & 10.5 & 10.5 & 12.0 & 14.0 & 13.0 & 13.0 \\
\hline$A m p-R(m m)$ & 8.0 & 8.5 & 8.5 & 13.0 & 14.0 & 14.0 & 9.5 & 9.5 & 10.0 & 13.0 & 12.0 & 12.0 \\
\hline Duration (msec.) & 40 & 40 & 40 & 40 & 30 & 40 & 40 & 40 & 40 & 40 & 40 & 40 \\
\hline $\begin{array}{l}Q-T \text { interval } \\
\text { (msec.) }\end{array}$ & 200 & 240 & 280 & 280 & 260 & 260 & 220 & 220 & 280 & 280 & 280 & 280 \\
\hline \multicolumn{13}{|l|}{ T-wave: } \\
\hline Amp.(mm) & 2.0 & 2.2 & 2.0 & 1.5 & 1.0 & 1.0 & 2.2 & 1.5 & 2.0 & 1.5 & 1.0 & 1.0 \\
\hline Duration (msec.) & 160 & 160 & 200 & 180 & 180 & 180 & 200 & 200 & 200 & 160 & 160 & 160 \\
\hline
\end{tabular}

* Mean of 4 observations.

Assiut Vet.Med.J. Vol. 18, No. 35, 1987. 
Table (3)

Analgesic effect of acetylsalicylic acid, ethanolic extract

of Anagallis arvensis plant and its total saponin in mice $(n=5)$

\begin{tabular}{|c|c|c|c|c|c|c|c|c|}
\hline \multirow{2}{*}{ Group } & \multirow{2}{*}{\multicolumn{2}{|c|}{$\begin{array}{l}\text { Dose } \\
\text { (mg/100 } \\
g \text { b.wt) }\end{array}$}} & \multicolumn{6}{|c|}{ Reaction time after administration (seconds) } \\
\hline & & & 10 mins & 20 mins & 30 mins & 45 mins & 60 mins & 120 mins \\
\hline 1. Control & & -- & $11.39+0.57$ & $11.35+0.63$ & $11.32+0.55$ & $11.46+0.66$ & $11.38+0.54$ & $11.36+0.55$ \\
\hline $\begin{array}{l}\text { 2. Acetylsa- } \\
\text { licylic acid }\end{array}$ & & 5.0 & $\begin{array}{l}14.50 \pm 0.65 * * \\
\therefore \quad(1.00)\end{array}$ & $\begin{array}{c}14.52+0.51 * * \\
(1.00)\end{array}$ & $\begin{array}{c}14.54+0.77 * * \\
(1.00)\end{array}$ & $\begin{array}{c}15.40 \pm 0.63 * * \\
(1.00)\end{array}$ & $\begin{array}{c}15.60+0.73 * * \\
(1.00)\end{array}$ & $\begin{array}{c}14.80+0.68^{* *} \\
(1.00)\end{array}$ \\
\hline $\begin{array}{l}\text { 3. Ethanolic } \\
\text { Extract }\end{array}$ & & 0.5 & $\begin{array}{c}11.84+0.51 \\
(0.15)\end{array}$ & $\begin{array}{c}11.88+0.39 \\
(0.17)\end{array}$ & $\begin{array}{c}11.82+0.43 \\
(0.16)\end{array}$ & $\begin{array}{l}11.78+0.45 \\
(0.08)\end{array}$ & $\begin{array}{c}11.92+0.35 \\
(0.13)\end{array}$ & $\begin{array}{c}11.85+0.43 \\
(0.14)\end{array}$ \\
\hline $\begin{array}{l}\text { 4. Ethanolic } \\
\text { Extract }\end{array}$ & & 1.0 & $\begin{array}{c}12.20+0.44 \\
(0.26)\end{array}$ & $\begin{array}{l}14.25+0.80 * \\
(0.92)\end{array}$ & $\begin{array}{l}13.33+0.41 * \\
(0.62)\end{array}$ & $\begin{array}{l}13.40+0.45 * \\
(0.49)\end{array}$ & $\begin{array}{l}13.38+0.45 * \\
(0.47)\end{array}$ & $\begin{array}{c}13.73+0.63 * \\
(0.69)\end{array}$ \\
\hline 5. Saponin & 4 & 0.2 & $\begin{array}{c}12.18+0.42 \\
(0.25)\end{array}$ & $\begin{array}{c}13.28+0.32 * \\
(0.61)\end{array}$ & $\begin{array}{c}14.21+0.55 * * \\
(0.90)\end{array}$ & $\begin{array}{c}14.42+0.57 * * \\
(0.75)\end{array}$ & $\begin{array}{c}14.50+0.53 * * \\
(0.74)\end{array}$ & $\begin{array}{c}14.45+0.50 * * \\
(0.90)\end{array}$ \\
\hline 6. Saponin & & 0.4 & $\begin{array}{c}13.95+0.61 * \\
(0.82)\end{array}$ & $\begin{array}{c}15.66 \pm 0.58 * * \\
(1.36)\end{array}$ & $\begin{array}{c}15.38+0.63^{* *} \\
(1.26)\end{array}$ & $\begin{array}{c}16.00+0.71 * * \\
(1.15)\end{array}$ & $\begin{array}{c}15.20+0.55 * * \\
(0.90)\end{array}$ & $\begin{array}{c}15.80+0.71 * * \\
(1.29)\end{array}$ \\
\hline
\end{tabular}

* $P \underline{1} 0.05 * * \quad P / 0.01$

N.B.: The value between two brackets indicates the potancy of the extract and saponin in relation to acetylsalicylic acid as standard. 
S.H. HILAL, et al.

Table (4)

Antipyretic effect of acetyl salcylic acid, ethanolic extract of Anagallis arvensis plant and its total saponin in hyperthermic rats $(n=5)$

\begin{tabular}{|c|c|c|c|c|c|}
\hline \multirow{2}{*}{\multicolumn{2}{|c|}{ Group }} & \multirow{2}{*}{$\begin{array}{l}\text { Dose } \\
\text { (mg/100 } \\
g \text { b.wt) }\end{array}$} & \multicolumn{3}{|c|}{ Mean rectal temprature $\left({ }^{\circ} \mathrm{C}\right)$ after } \\
\hline & & & $1 \mathrm{hr}$ & $2 \mathrm{hrs}$ & $3 \mathrm{hrs}$ \\
\hline 1. & Control & $-\cdots$ & $38.55 \pm 0.30$ & $38.60+0.45$ & $38.50+0.40$ \\
\hline & $\begin{array}{l}\text { Acetyl salicylic } \\
\text { acid }\end{array}$ & 5 & $\begin{array}{c}37.00+0.20 * * \\
(1.00)\end{array}$ & $\begin{array}{c}36.80 \pm 0.20 * * \\
(1.00)\end{array}$ & $\begin{array}{c}36.90+0.20 * * \\
(1.00)\end{array}$ \\
\hline 3. & Extract & 0.5 & $\begin{array}{c}38.50+0.20 \\
(0.03)\end{array}$ & $\begin{array}{c}38.58+0.40 \\
(0.01)\end{array}$ & $\begin{array}{c}38.50+0.40 \\
(0.00)\end{array}$ \\
\hline 4. & & 1.0 & $\begin{array}{c}37.90+0.21 \\
(0.42)\end{array}$ & $\begin{array}{c}38.00+0.10 \\
(0 . \overline{3} 3)\end{array}$ & $\begin{array}{c}38.10+0.15 \\
(0.25)\end{array}$ \\
\hline 5. & Saponin & 0.2 & $\begin{array}{c}37.50+0.10^{*} \\
(0.68)\end{array}$ & $\begin{array}{c}37.60+0.15 \\
(0.56)\end{array}$ & $\begin{array}{c}37.80+0.15 \\
(0.44)\end{array}$ \\
\hline 6. & & 0.4 & $\begin{array}{c}37.25 \pm 0.10 * * \\
(0.84)\end{array}$ & $\begin{array}{c}37.40+0.15 * \\
(0.77)\end{array}$ & $\begin{array}{c}37.50+0.20 \\
(0.63)\end{array}$ \\
\hline
\end{tabular}

* $P$ / $0.05 \quad * * P / 0.01$

( ) Indicates the potancy of extract and saponin in relation to acetylsalcylic acid as standard.

Table (5)

Antinflammatory effect phenylbutazone, ethanolic extract of Anagallis arvensis plant and its total saponin in mature rats $(n=5)$

\begin{tabular}{lccc}
\hline \multicolumn{1}{c}{ Groups } & $\begin{array}{c}\text { dose } \\
(\mathrm{mg} / 100 \mathrm{~g} \\
\text { b.wt })\end{array}$ & $\begin{array}{c}\text { Mean of swelling } \\
\text { of foot }(\mathrm{mm}) \pm \text { S.E }\end{array}$ & Potancy \\
\hline Control & $-\cdots$ & $0.44 \pm 0.05$ & - \\
Phenylbutazone & 15 & $0.25 \pm 0.01 * *$ & 1 \\
Extract & 0.5 & $0.42 \pm 0.04$ & 0.11 \\
& 1.0 & $0.40 \pm 0.06$ & 0.21 \\
Saponin & 0.2 & $0.40 \pm 0.06$ & 0.21 \\
& 0.4 & $0.35+0.01$ & 0.47 \\
\hline
\end{tabular}

** P $\underline{0.001}$

Assiut Vet.Med.J. Vol. 18, No. 35, 1987. 


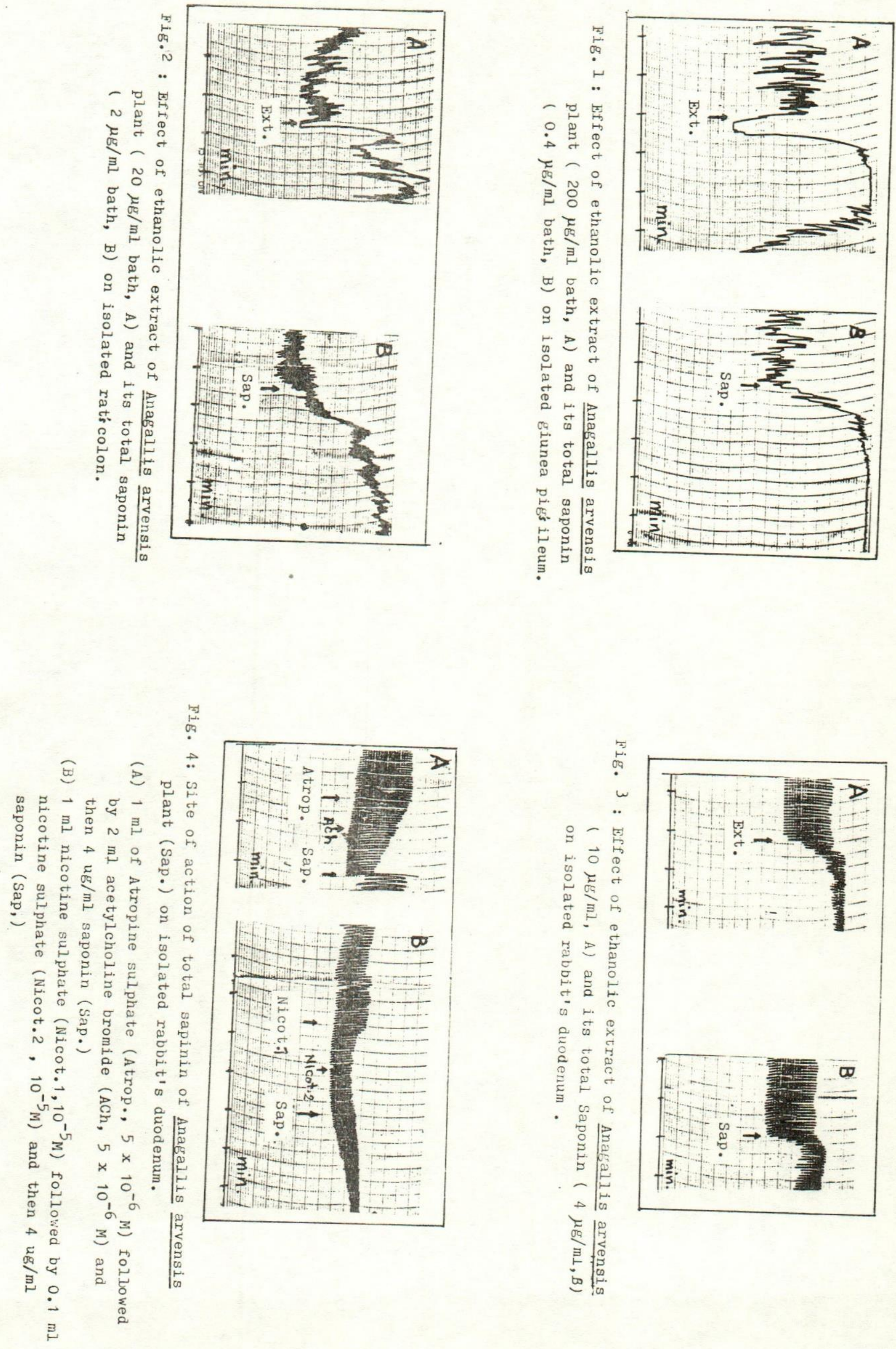


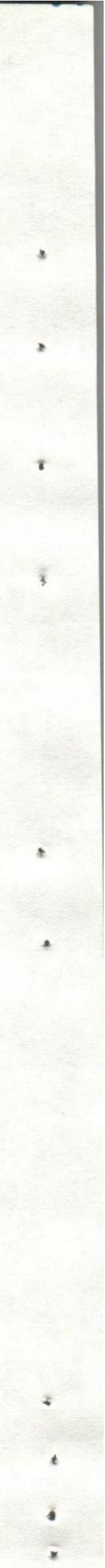



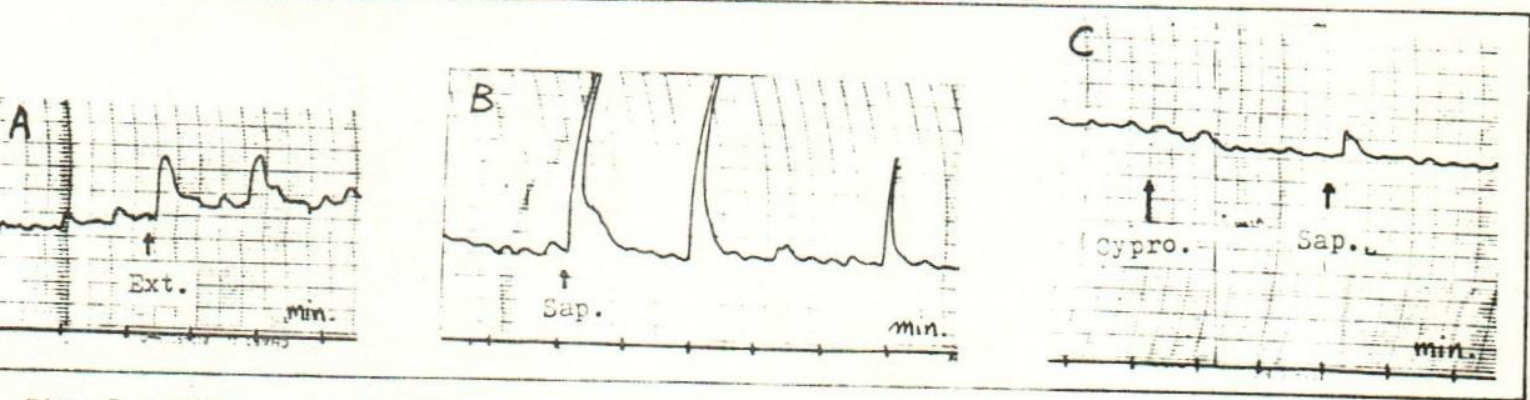

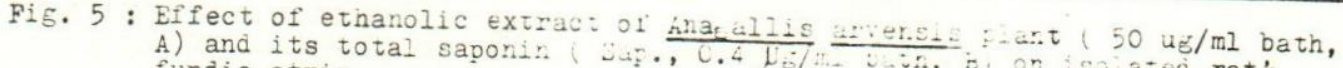

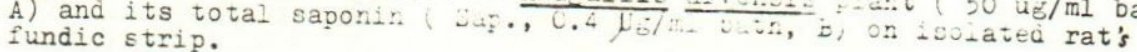

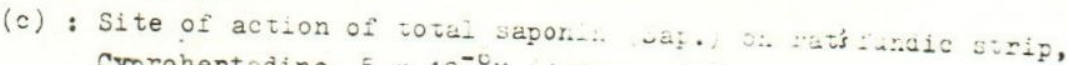

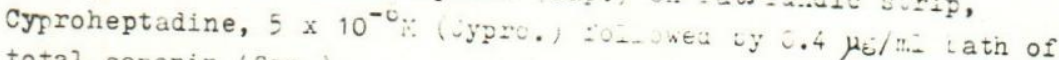
total saponin (Sap.).

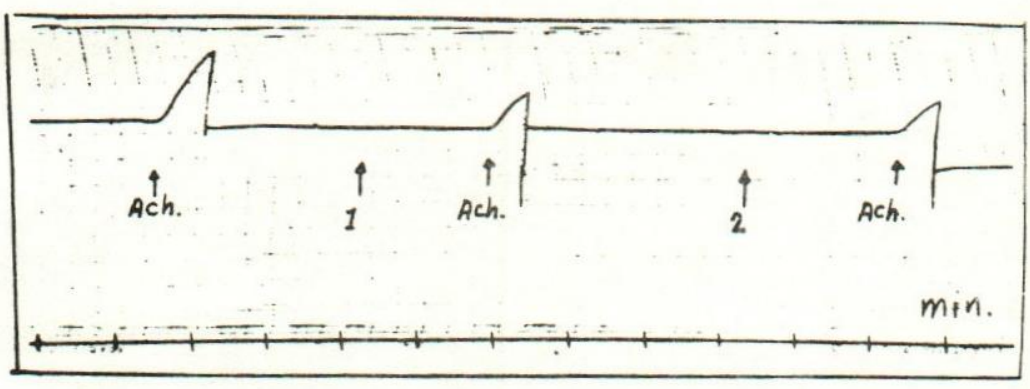

ig. c: Eliect of etnanolic extract of hncöallis arvensis (Ext.) plant anc is total saporin on acetylcnoline-induced contractions in the $\mathrm{FO}_{\mathrm{g}}$ rectus atcominis muscle preparation. Tne muscle was mounted in aerated Ringer's SOl. ke: $:$ at room temrature.

( $h$ Ch) : icetyl croine $(2 \mathrm{ug} / \mathrm{ml})$.

(1) : Extract $100 \mu \mathrm{g} / \mathrm{mz})$.

(2): Japonin $(10 \mu \mathrm{g} / \mathrm{mi})$.
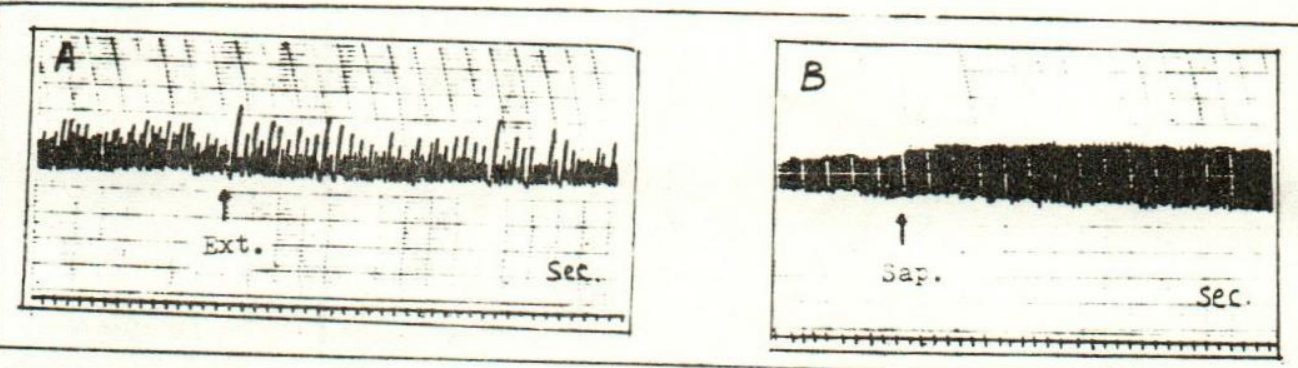

Fig. 7 : Effect of etnanuic tairact (Ext.) o in

$(0.5 \mu \mathrm{g} / \mathrm{ml}, \mathrm{A})$ and is totaj sapon Anasell anvenes plant

contractions of isolated ravbitis neat. $\cdots+\mu_{6} / \cdots i$,
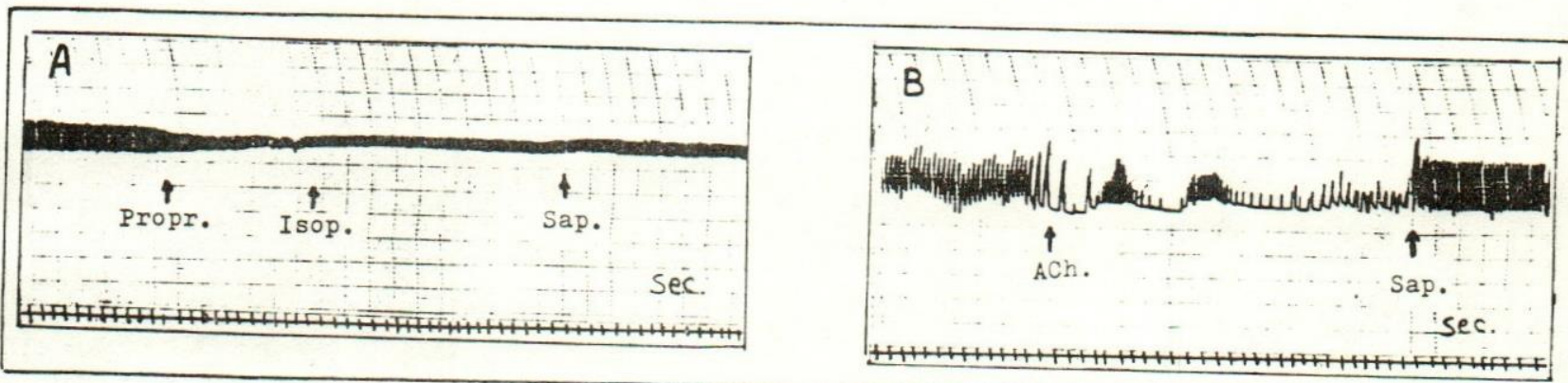

Fig. 8 : Site of action of total isolated saponin (Sap.) of Anacillis arvensis plant on isolated rabbit's heart.

(A) : Propranolol, $2 \times 10^{-5} \mathrm{~N} \mathrm{SOl.} \mathrm{(Propr.)} \mathrm{followed} \mathrm{by} \mathrm{isoprenaline,}$

(B) Acetylcholine, $5 \times 10^{-5} \mathrm{~m}$ then by $0.25 \mu \mathrm{g} / \mathrm{ml}$ of Saponin(Sap.). saponin (Sap.). 


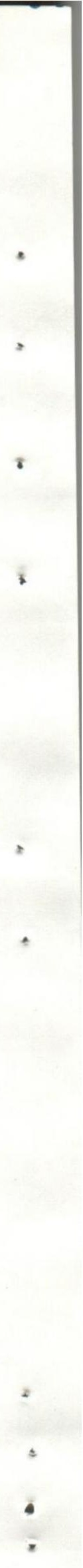




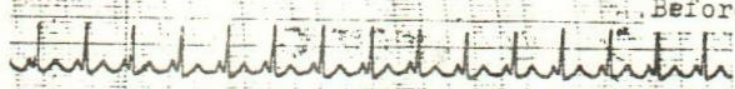

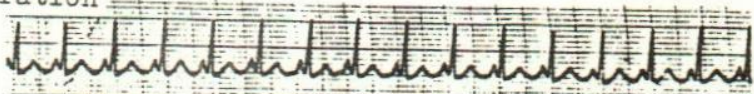

After administration

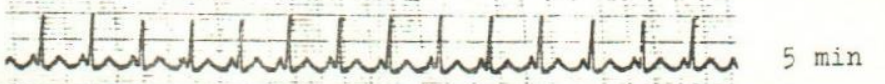

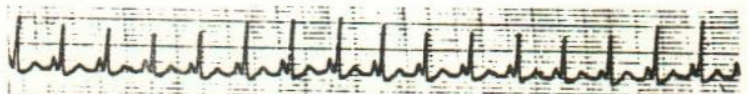

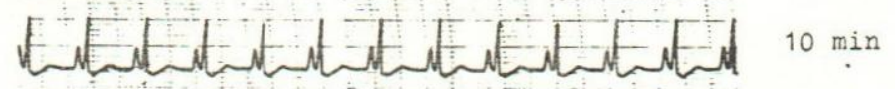

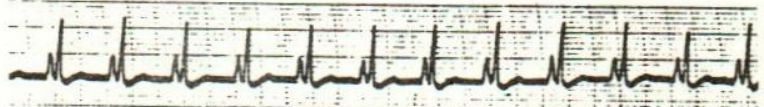

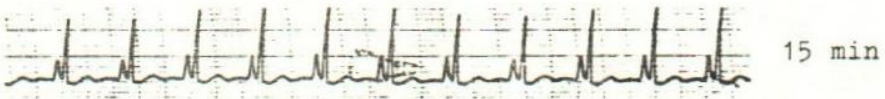

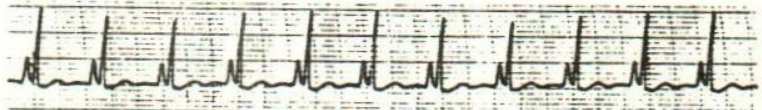

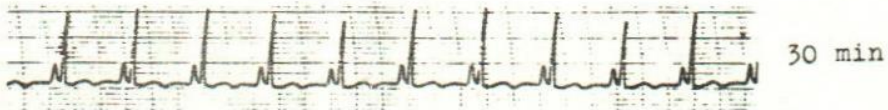

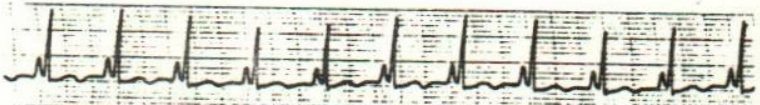

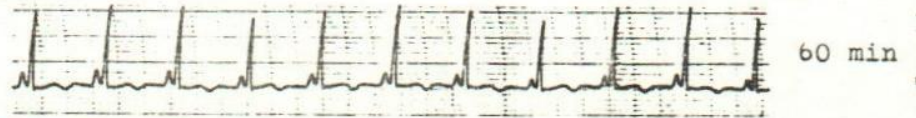

Entut

Fi. 11: Effect of intravenous injection of etnanolic extract of Anagallis arvensis

plant ( $9 \mathrm{mg} / \mathrm{kg}$ b.wt.) and its total saponin ( $3 \mathrm{mg} / \mathrm{kg}$ b.wt.) on the

electrocaraiogram ( Lead II) of anaesthetized dogs ( speed $=25 \mathrm{~mm} / \mathrm{sec}$.).

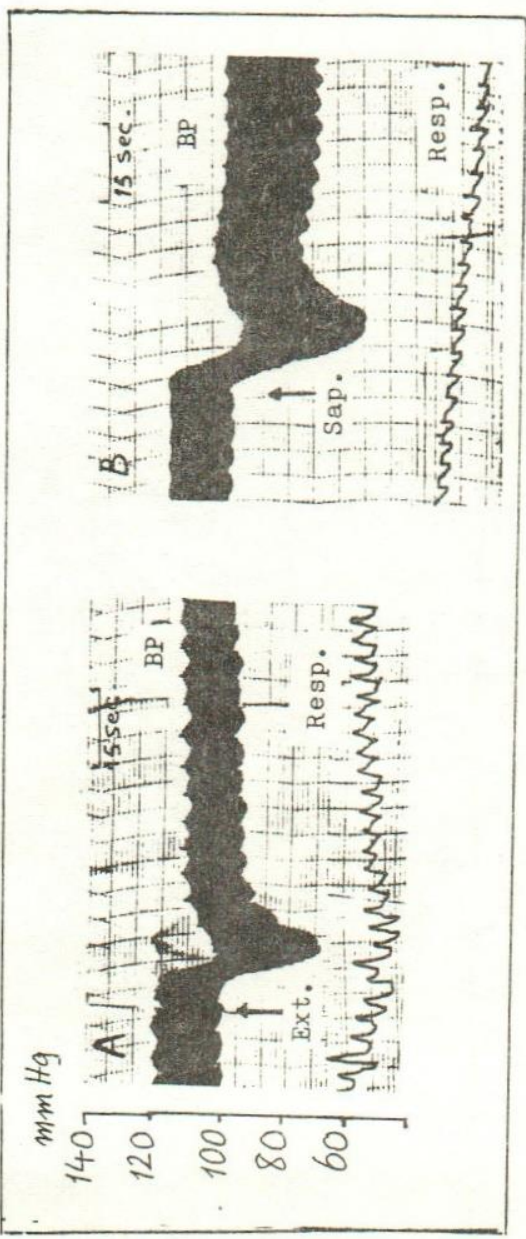

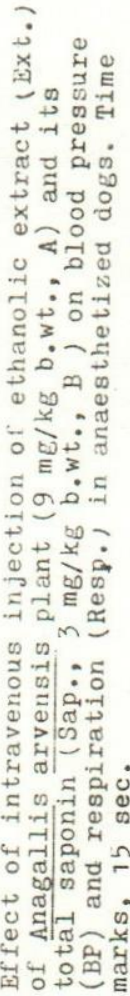

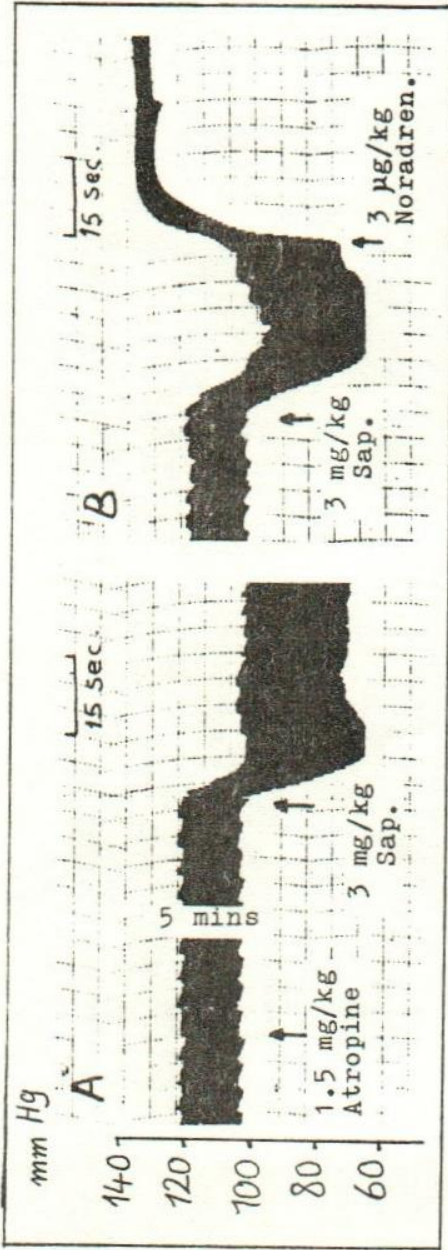



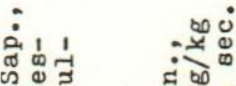

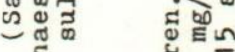

द สิ

동드웡

乐

之心

ฮึ

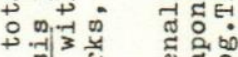

4 ํㅐㅇㅠ

+ 뉭 क्षैत्

:

令丮.

( ) तो

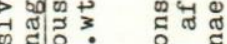

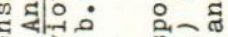

넝 o

วิ่า

年

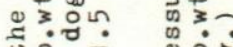

क

ही

7 व

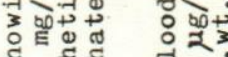

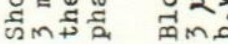

a

-

$\ddot{4}$

$\ddot{n}$

..

우

$\dot{0}$ 